DNA Library of Life, research article

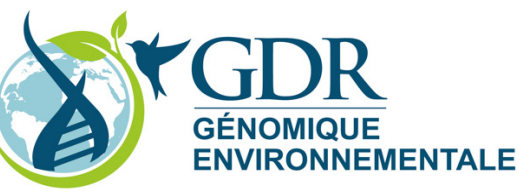

urn:1sid:zoobank.org:pub:E0654D20-49F5-477D-ABA1-3DC89B96939D

\title{
Not all spotted cats are leopards: evidence for a Hemilienardia ocellata species complex (Gastropoda: Conoidea: Raphitomidae)
}

\author{
Alexander E. FEDOSOV ${ }^{1, *}$, Peter STAHLSCHMIDT ${ }^{2}$, Nicolas PUILLANDRE ${ }^{3}$, \\ Laetitia AZNAR-CORMANO ${ }^{4} \&$ Philippe BOUCHET $^{5}$ \\ ${ }^{1}$ A.N. Severtsov Institute of Ecology and Evolution, Russian Academy of Science, \\ 119071, Leninsky prospect, 33, Moscow, Russia. \\ ${ }^{2}$ Institute for Environmental Sciences, University of Koblenz-Landau, \\ Fortstr. 7, 76829 Landau, Germany. \\ ${ }^{3,4}$ Institut de Systématique, Évolution, Biodiversité ISYEB - UMR 7205 - CNRS, \\ MNHN, UPMC, EPHE, Muséum national d'Histoire naturelle, Sorbonne Universités, \\ 43 rue Cuvier, CP26, F-75005, Paris, France. \\ ${ }^{5}$ Institut de Systématique, Évolution, Biodiversité ISYEB - UMR 7205 - CNRS, \\ MNHN, UPMC, EPHE, Muséum national d'Histoire naturelle, Sorbonne Universités, \\ 55 rue Buffon, CP26, F-75005, Paris, France. \\ *Corresponding author: fedosovalexander@gmail.com \\ ${ }^{2}$ Email: stahlschmidt2@uni-landau.de \\ ${ }^{3}$ Email: puillandre@mnhn.fr \\ ${ }^{4}$ Email: aznar.laetitia@gmail.com \\ ${ }^{5}$ Email: pbouchet@mnhn.fr
}

\footnotetext{
${ }^{1}$ urn:lsid:zoobank.org:author:65A25D60-A36D-48E5-9A03-B21207A0FAE2

${ }^{2}$ urn:1sid:zoobank.org:author:4A571034-ECA3-455C-8DA3-7B12FD638AC0

${ }^{3}$ urn:1sid:zoobank.org:author:00565F2A-C170-48A1-AAD9-16559C536E4F

${ }^{4}$ urn:lsid:zoobank.org:author:C070F6C9-63C3-47B8-9C5B-683412F65E25

${ }^{5}$ urn:lsid:zoobank.org:author:FC9098A4-8374-4A9A-AD34-475E3AAF963A
}

\begin{abstract}
The small conoidean Hemilienardia ocellata is one of the easily recognizable Indo-Pacific "turrids", primarily because of its remarkable eyespot colour pattern. Morphological and molecular phylogenetic analyses revealed four species that share this "characteristic" colour pattern but demonstrate consistent differences in size and shell proportions. Three new species - Hemilienardia acinonyx sp. nov. from the Philippines, $H$. lynx sp. nov. from Papua New Guinea and $H$. pardus sp. nov. from the Society and Loyalty Islands - are described based on the results of phylogenetic analyses. Although the $H$. ocellata species complex clade falls in a monophyletic Hemilienardia, H. ocellata and H. acinonyx sp. nov. possess a radula with semi-enrolled or notably flattened triangular marginal teeth, a condition that diverges substantially from the standard radular morphology of Hemilienardia and other raphitomids.
\end{abstract}

Keywords. Integrative taxonomy, species delimitation, Indo-Pacific, COI, 16S. 
Fedosov A.E., Stahlschmidt P., Puillandre N., Aznar-Cormano L. \& Bouchet P. 2017. Not all spotted cats are leopards: evidence for a Hemilienardia ocellata species complex (Gastropoda: Conoidea: Raphitomidae). European Journal of Taxonomy 268: 1-20. http://dx.doi.org/10.5852/ejt.2017.268

\section{Introduction}

Colour patterns with eyespots (ocellae) are widespread in the animal world and have obviously a great adaptive significance (Allen et al. 2011). Besides in various groups of seaslugs, ocellae may be present on the head-foot (as, e.g., in many ranellids and a few cancellariids) or mantle (as, e.g., in many ovulids and some eulimids) of shelled gastropods, or, alternatively, they may be part of the colour pattern of the shell (as, e.g., in various phasianellids, cowries, and columbellids). One of the iconic gastropod species with such a remarkable colour pattern is Hemilienardia ocellata (Jousseaume, 1884), a tiny shallow water Indo-Pacific raphitomid (Conoidea, Raphitomidae). The shell of this species is decorated with a bright yellow spiral line and regular olive green ovate spots fringed by brown, situated adapically of the yellow line in the interspaces between axial ribs, resembling a row of olives laid on a golden tray. This picturesque species, despite apparently being widely distributed in the tropical Indo-Pacific (Jousseaume 1884; Hedley 1922; B.J. Smith 2003; Tröndlé \& Boutet 2005; Héros et al. 2007; Sysoev 2008), is, however, seldom encountered because of its minute size (its shell barely reaches a length of $5 \mathrm{~mm}$ ), which helps it escape collecting by hand-picking.

Novel collecting techniques, that are routinely referred to as "brushing" and "air lifting", have been developed to efficiently sample micro-molluscs associated with coral reefs at divable depths (Bouchet et al. 2002). They were first introduced in expedition routine in the 1990s in large scale surveys in New Caledonia and the Loyalty Islands in near-shore marine habitats and, later, in the Philippines, Papua New Guinea, Vanuatu and Madagascar. From one 30000 hectare site in New Caledonia, 2738 morphospecies of molluscs were recovered, and a significant fraction (263 species) of this huge diversity belonged to the so-called turriform Conoidea. Among them, three distinct forms were referable to Hemilienardia ocellata which differed notably in shell proportions, but with these differences hidden under a remarkably similar eyespot colour pattern. However, in the absence of molecular data, the status of these forms remained uncertain. In more recent expeditions, the development of a new protocol for the separation of bodies and shells (Galindo et al. 2014) has allowed the building of large tissue collections for molecular analysis, and has allowed us to revisit the case of these divergent morphotypes of Hemilienardia ocellata.

\section{Material and methods}

\section{Material}

The material for the present study was collected at various Indo-Pacific localities in a series of shallow water expeditions to New Caledonia (Expedition Montrouzier - 1993), the Loyalty Islands (Atelier Lifou2000), Vanuatu (SANTO 2006) and Papua New Guinea (PAPUA NIUGINI 2012, KAVIENG 2014). This core dataset was supplemented by molecular-grade specimens obtained in 2008 in the Central Philippines (Cebu-Bohol area) from bulk lumun-lumun nets (Seronay et al. 2010), and in the Society Islands in the course of the Moorea Biocode Project (http://mooreabiocode.org/). Live specimens for molecular analysis collected before 2012 were anaesthetized in an isotonic solution of $\mathrm{MgCl}_{2}$ and fixed in $96 \%$ ethanol. Specimens collected in later expeditions were processed with a microwave oven: the living mollusks in small volumes of sea water were exposed to microwaves for 7-12 seconds, depending on the specimen size. Bodies were immediately removed from shells and dropped in $96 \%$ ethanol; intact voucher shells are kept in MNHN. The collection data for sequenced specimens are summarized in Table 1. Despite the former having long been considered a subgenus of the latter, the genera 


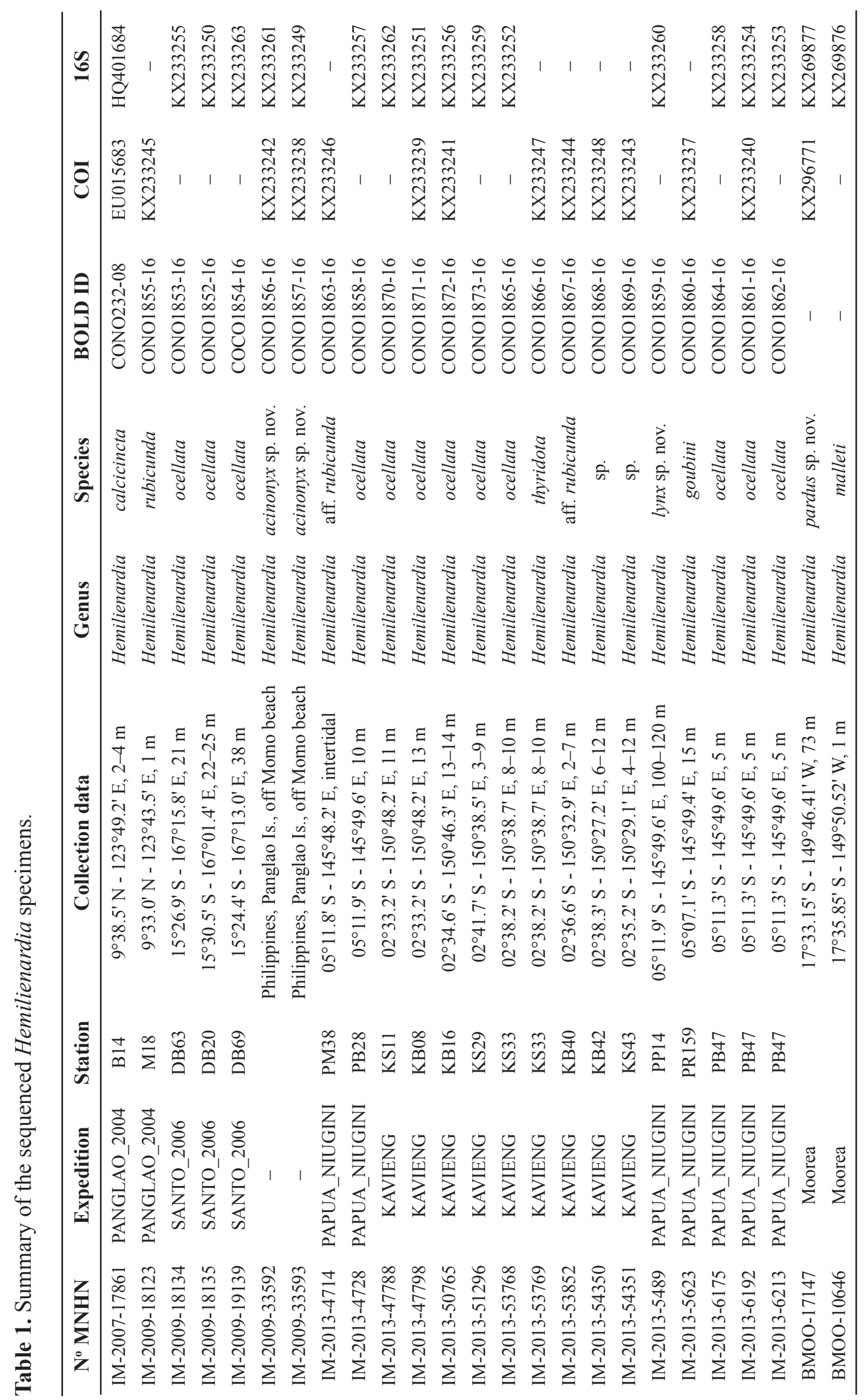


Hemilienardia O. Boettger, 1895 and Lienardia Jousseaume, 1884 are not closely related and not even confamilial (Bouchet et al. 2011), and comparisons here will be limited to other raphitomids.

\section{DNA extraction and PCR}

Total DNA was extracted from a piece of the foot using the Dneasy96 Tissue kit (Qiagen), following the manufacturer's recommendations. The barcode fragment of the COI gene (658 bp) and a 16S rRNA fragment were amplified using the universal primers LCO1490 and HCO2198 (Folmer et al. 1994) and a primer pair 16SH-16LC (Palumbi 1996), respectively. PCR reactions were performed in $25 \mu \mathrm{l}$, containing $3 \mathrm{ng}$ of DNA, $10 \times$ reaction buffer containing $15 \mathrm{mM} \mathrm{MgCl} 2,0.26 \mathrm{mM} \mathrm{dNTP}, 0.3 \mu \mathrm{M}$ of each primer, $5 \%$ DMSO, $1 \mathrm{mg} / \mathrm{ml} \mathrm{BSA}$ and 1 unit of QBiotaq (MPBiomedicals). Amplification of COI consisted of an initial denaturation step at $95^{\circ} \mathrm{C}$ for $5 \mathrm{~min}$, followed by 35 cycles of denaturation at $95^{\circ} \mathrm{C}$ for $40 \mathrm{~s}$, annealing at $50^{\circ} \mathrm{C}$ for $30 \mathrm{~s}$, followed by extension at $72^{\circ} \mathrm{C}$ for $1 \mathrm{~min}$. For $16 \mathrm{~S}$ the annealing temperature was set to $50^{\circ} \mathrm{C}$ and the elongation phase to $50 \mathrm{~s}$. The final extension was at $72^{\circ} \mathrm{C}$ for $5 \mathrm{~min}$. PCR products were purified and sequenced by the Eurofins sequencing facility. Both directions were sequenced to confirm accuracy of each sequence.

The use of the barcode fragment of the COI sequence is preferable for purposes of species delimitation (Puillandre et al. 2012); however, amplification of COI encountered certain difficulties in many specimens, probably because of a mutation in the primer sequence. Thus, we mostly relied on the relationships inferred from the analysis of $16 \mathrm{~S}$ to suggest hypotheses of species delimitation.

\section{Species delimitation and phylogenetic analysis}

We followed a two-step approach to propose species hypotheses. First, all specimens were separated into morphospecies based on shell characters. Then, the COI and $16 \mathrm{~S}$ sequences were used to test (i) if the genetic distances between morphospecies were higher, than within morphospecies, and (ii) if each morphospecies corresponded to a clade (when represented by several sequenced specimens) or an independent lineage (when represented by a single sequenced specimen).

COI and 16S sequences were aligned using Muscle (Edgar 2004); the accuracy of each alignment was checked by eye and if needed modified using BioEdit v. 7.0.9.0 (Hall 1999). The best fit substitution model was estimated for each gene with Modelgenerator v. 85 (Keane et al. 2006). A set of COI and $16 \mathrm{~S}$ raphitomid sequences accessed from GenBank was used to root the tree and assess affinities of the Hemilienardia ocellata species complex. Phylogenetic analyses were performed using MrBayes (Huelsenbeck et al. 2001), running two parallel analyses, each consisting of six Markov chains of 20000000 generations with a sampling frequency of one tree each 1000 generations, with a chain temperature of 0.02. Parameters of the substitution model were estimated during the analysis ( 6 substitution categories, a gamma-distributed rate variation across sites approximated in four discrete categories and a proportion of invariable sites). A different model of substitution was applied for each codon position of the COI gene. Trees from the first 5000000 generations ( $25 \%$ of the total number of generations) were discarded as burn-in prior to the construction of consensus trees. Convergence of each analysis was evaluated using Tracer v. 1.4.1 (Rambaut et al. 2014) to check that ESS values were all greater than 200 (default burning). K2P genetic distances were calculated with MEGA v. 5.2.1 (Tamura et al. 2011).

\section{Morphological studies}

Radulae were extracted from specimens in which the body had been dried. The specimens were rehydrated over 2-3 hours, then a hole was drilled on the penultimate whorl of the shell, at about the place where the columellar muscle is attached, to ease extraction of the body. Rehydrated bodies were then dissected and buccal complexes treated by a solution of commercially available bleach until radulae were clean. Radulae were then rinsed in distilled water, mounted on a cover glass, air-dried, 
gold coated and examined with a Hitachi CamScan scanning electron microscope. A Fei Quanto 250 environmental scanning electron microscope (ESEM) was used without preliminary coating to examine the fine morphology of protoconchs and shells, as it was essential to keep specimens uncoated (e.g., in case of examination of putative holotypes).

Abbreviations of museums and repositories:

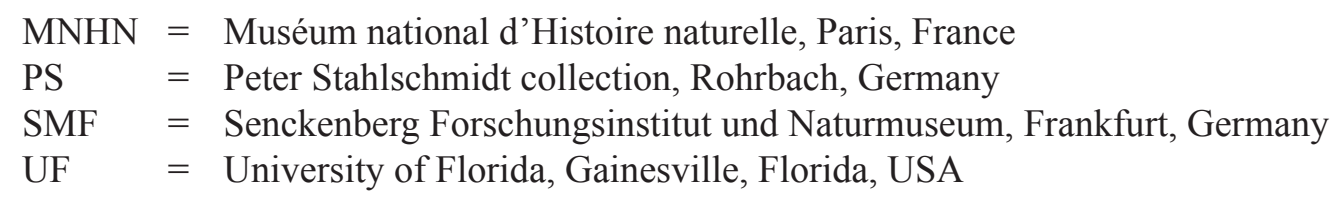

Other abbreviations:

$\mathrm{b} / \mathrm{h}=$ ratio of shell breadth to its height

$\mathrm{lw} / \mathrm{h}=$ ratio of last adult whorl length (measured along main shell axis) to total shell height

$\mathrm{a} / \mathrm{h}=$ ratio of aperture length (measured along main shell axis) to total shell height

PI, PII = protoconch I and protoconch II

$\mathrm{dd} \quad=$ empty shell

lv $=$ live-collected specimen

$\mathrm{SD} \quad=$ standard deviation

\section{Results}

\section{Species delimitation and phylogenetic analysis}

GTR $+\mathrm{I}+\mathrm{G}$ was selected as a best fit substitution model for the COI, and HKY $+\mathrm{I}+\mathrm{G}$ for the $16 \mathrm{~S}$ rRNA gene. The phylogenetic trees obtained after the analysis of COI and $16 \mathrm{~S}$ were largely congruent, with no conflicting topologies highly supported (Fig. 1).

Four morphospecies were identified. The pairwise distances (p-distances) calculated for the COI sequences vary from 0 to 0.03 for within-morphospecies comparisons $($ mean $=0.016, \mathrm{SD}=0.0157$ ) and from 0.157 to 0.169 for comparisons between morphospecies (mean $=0.162$, $\mathrm{SD}=0.0037$ ). The p-distances calculated for the $16 \mathrm{~S}$ sequences vary from 0 to 0.027 for within-morphospecies comparisons (mean $=0.012, \mathrm{SD}=0.0072$ ) and from 0.069 to 0.104 for comparisons between morphospecies (mean $=0.082, \mathrm{SD}=0.0109$ ). As the between-group genetic distances (especially for the COI gene) are greater than genetic distances between closely related species of conoideans found in our earlier studies (e.g., Puillandre et al. 2009, 2010; Fedosov \& Puillandre 2012), the genetic differences found within the $H$. ocellata species complex support the species hypotheses based on the identified morphospecies.

Based on the results of both phylogenetic analyses, the Hemilienardia ocellata species complex forms a well supported clade (Posterior Probabilities $(\mathrm{PP})=1$ and 0.99 for COI and $16 \mathrm{~S}$, respectively). Three distinct lineages are recognized on the COI based tree (marked as 1 to 3 on Fig. 1A), each corresponding to one morphospecies. One includes specimens MNHN IM-2013-6192, MNHN IM-2013-47798 and MNHN IM-2013-50675, all from Papua New Guinea $(\mathrm{PP}=1)$; the second clade includes two Philippine specimens, MNHN IM-2009-33592 and MNHN IM-2009-33593, sharing an identical COI haplotype $(\mathrm{PP}=1)$; specimen $\mathrm{BMOO}-17147$ from Moorea constitutes the third lineage. The first and second clades cluster together with a high support $(\mathrm{PP}=0.99)$. The Hemilienardia ocellata species complex is nested within the unsupported Hemilienardia clade $(\mathrm{PP}=0.73)$.

Sixteen Hemilienardia ocellata specimens sequenced for $16 \mathrm{~S}$ form four distinct groupings (Fig. 1B), once again each corresponding to one morphospecies. The largest of them combines 12 specimens from Papua New Guinea and Vanuatu, and is consistent with the first grouping on the COI based tree. 
Interestingly, three specimens from Vanuatu form a rather distinct supported sub-clade ( $\mathrm{PP}=0.98)$, although with a very short branch. The second clade contains two specimens from the Philippines and is consistent with the COI based tree. The third and fourth lineages include one specimen each, MNHN IM2013-5489 from Papua New Guinea and BMOO 17147 from Moorea, respectively. These two lineages cluster together $(\mathrm{PP}=1)$ and show a supported affinity to the second clade $(\mathrm{PP}=0.97)$. The grouping of Hemilienardia malleti (Récluz, 1852) BMOO 10646 and H. calcicincta (Melvill \& Standen, 1895) MNHN IM-2007-17861 is a sister-group to the entire H. ocellata species complex clade. Hemilienardia is recovered monophyletic and supported $(\mathrm{PP}=0.99)$ based on the analysis of $16 \mathrm{~S}$. The application of the name Hemilienardia to this clade is verified by the inclusion of $H$. malleti, the type species of the genus.

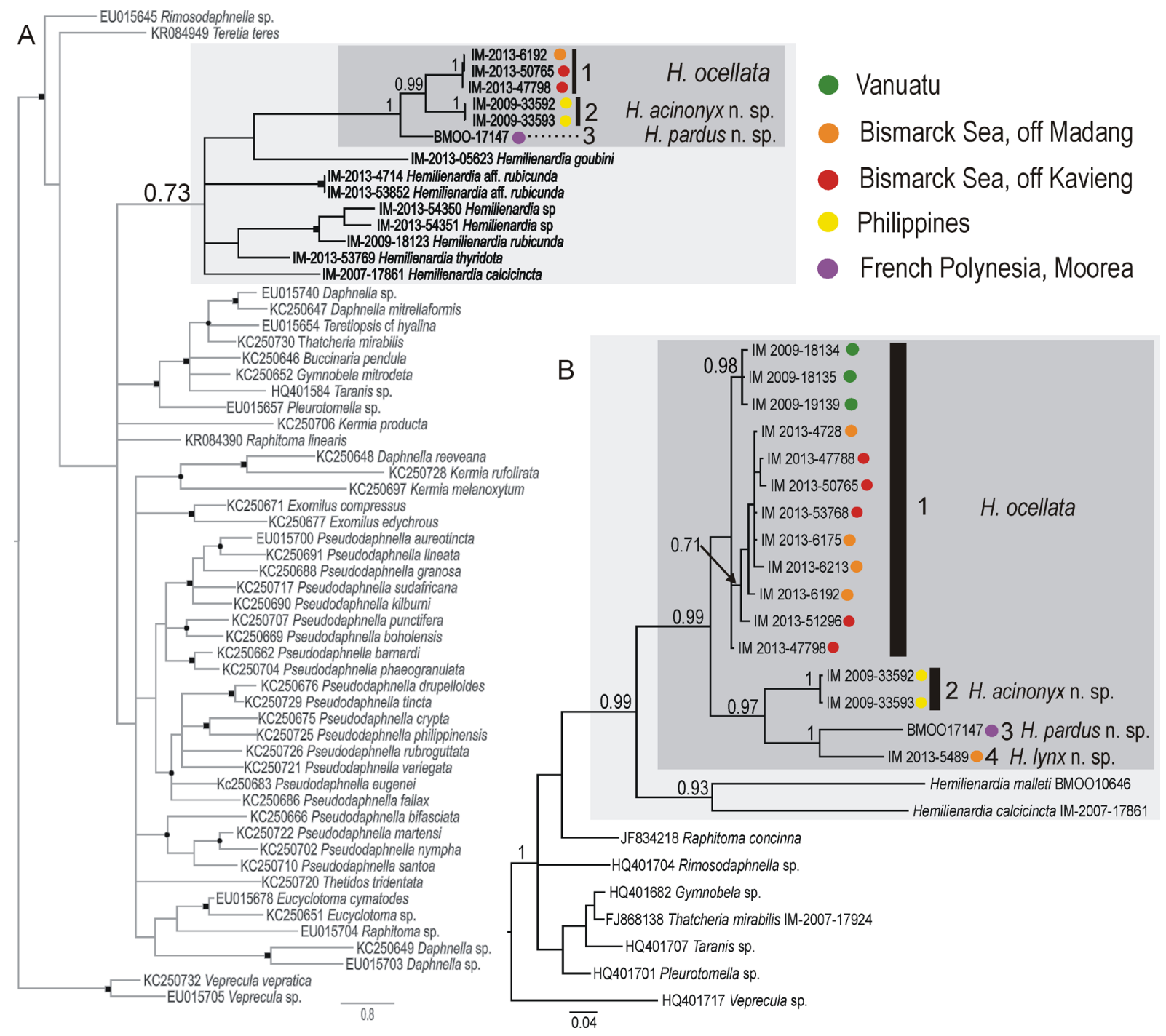

Fig. 1. Relationships of the Hemilienardia ocellata complex as inferred by the molecular phylogenetic analysis. A. Bayesian tree based on the analysis of 61 Raphitomidae COI sequences. Black circles indicate nodes with $0.9<\mathrm{PP} \leq 0.97$, squares nodes with $0.98<\mathrm{PP} \leq 1$. Light grey area marks the Hemilienardia segment of the tree, dark grey the Hemilienardia ocellata species complex. Localities indicated as explained in legend. B. Bayesian tree based on the analysis of 25 Raphitomidae 16S sequences. Support values $(\mathrm{PP})$ indicated when $>0.7$. 
Two Philippine specimens are remarkable in that they greatly (more than two times) exceed other sequenced specimens in size. Moreover, the specimens that form the first group are characterized by ovate spots, while these are squarish in specimens that form groups 2, 3 and 4 on the 16S based tree.

With both genes, identified morphospecies corresponded to independent lineages or clades (supported for most of them) when several specimens were included. It, thus, further reinforces the species hypotheses proposed with morphological data. There is only one species name available for this complex, $H$. ocellata, and, based on the comparison of shell vouchers and the H. ocellata type material, we conclude that this name should be applied to the first species hypothesis. Nevertheless, the type locality of H. ocellata is Mauritius, whereas all sequenced specimens were recovered from the Central IndoWest Pacific. Although H. ocellata occur throughout the Indo-Pacific, remaining seemingly invariant in morphology, the possibility exists that the sequenced material represents a separate species. However, to test this hypothesis molecular material from Mauritius is needed, and it remains inaccessible for the time being, and thus we adhere to a more parsimonious assumption of $H$. ocellata being a single species throughout Indo-Pacific.

Two other species that correspond to the groups 2 and 3 of our $16 \mathrm{~S}$ based tree are here described as Hemilienardia acinonyx sp. nov. and H. lynx sp. nov., with holotypes selected from the sequenced vouchers. The specimen BMOO 17147, which constitutes the fourth species revealed by the molecular studies, is a subadult and it was unfortunately damaged while its tissue was clipped. In our opinion, this specimen would not constitute an adequate name-bearing type. Two additional $\mathrm{H}$. ocellata-like empty shells from the Society Islands were found to be morphologically conspecific with the BMOO 17147 voucher. Similar specimens with rather biconic shells and a very long siphonal canal were collected in New Caledonia and the Loyalty Islands; however, none was available for sequencing. We assume that they belong to the same species as the specimens from the Society Islands (the fourth species hypothesis) and we describe it here as $H$. pardus sp. nov.

There is a conflict between the two studied markers with regard to the relationships between species in the $H$. ocellata complex. Based on the analysis of COI, $H$. acinonyx sp. nov. forms a sister group to $H$. ocellata $(\mathrm{PP}=0.99)$, whereas based on the analysis of $16 \mathrm{~S}, H$. acinonyx sp. nov. is closer to $H$. lynx sp. nov. and $H$. pardus sp. nov., although this result is not strongly supported. As relationships within the $H$. ocellata species complex are not specifically targeted in the present study, and the phylogenetic analysis was performed for the species delimitation purposes only, this conflict does not alter our conclusions.

\section{Taxonomic account}

Class Gastropoda Cuvier, 1795

Order Neogastropoda Wenz, 1938

Superfamily Conoidea Flemming, 1822

Family Raphitomidae Bellardi, 1875

Genus Hemilienardia O. Boettger, 1895

\section{Type species}

Pleurotoma malleti Récluz, 1852 (by original designation).

Hemilienardia ocellata (Jousseaume, 1884)

Figs 2A-D, 3A-C, 4B

Lienardia ocellata Jousseaume, 1884: 186, pl. 4, fig. 4. 
Lienardia (Hemilienardia) ocellata - Powell 1966.

Hemilienardia ocellata - Hedley 1922: 297. — Loch 1992: 3, fig. 4. — B.J. Smith 2003: 257. — Sysoev 2008: 744, pl. 667, figs 5-6.

\section{Material examined}

Syntype

MAURITIUS: 4.0 mm (dd - Fig. 2A-B) (MNHN IM-2000-3128).

\section{Other material}

MALDIVES: Ari Atoll, Maagau Kandu, 25 m, private collection of S. Gori (1 dd, 3.1 mm - Fig. 3A).

PHILIPPINES: PANGLAO 2004: stn B1, Panglao Island, Alona Reef, 9³3.0' N, $123^{\circ} 46.5^{\prime} \mathrm{E}$, 8-14 m (2 lv, $3.3 \mathrm{~mm}, 3.4 \mathrm{~mm})$; stn B2, Panglao Island, Alona Reef, 9 $33.0^{\prime} \mathrm{N}, 123^{\circ} 46.5^{\prime} \mathrm{E}, 5 \mathrm{~m}(1 \mathrm{lv}$, $2.8 \mathrm{~mm}$ ); stn B10, Panglao Island, Momo Beach, $9^{\circ} 36.5^{\prime} \mathrm{N}, 123^{\circ} 45.6^{\prime} \mathrm{E}, 3-14 \mathrm{~m}$ (1 lv, $\left.2.8 \mathrm{~mm}\right)$; stn B13, Bohol Island, Baclayon Takot, $9^{\circ} 37.1^{\prime} \mathrm{N}, 123^{\circ} 52.6^{\prime} \mathrm{E}, 3-5 \mathrm{~m}$ (2 lv, $\left.2.8 \mathrm{~mm}, 3.2 \mathrm{~mm}\right)$; stn B17, Panglao Island, Bingag, $9^{\circ} 37.5^{\prime} \mathrm{N}, 123^{\circ} 46.9^{\prime} \mathrm{E}, 3-21 \mathrm{~m}(1 \mathrm{lv}, 2.9 \mathrm{~mm})$; stn B20, Bohol Island, Ubajan, $9^{\circ} 41.5^{\prime} \mathrm{N}$,

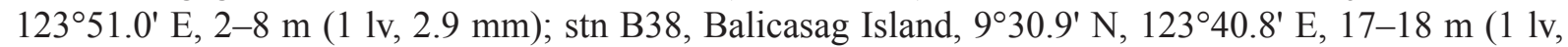
$2.7 \mathrm{~mm}$ ); stn L69-73, Balicasag Island, 9³0.7' N, 12340.9' E, 90-98 m (1 dd); stn L74-75, Balicasag Island, $9^{\circ} 30.7^{\prime} \mathrm{N}, 123^{\circ} 40.9^{\prime} \mathrm{E}, 120-139 \mathrm{~m}$ (1 lv, $3.4 \mathrm{~mm}$ ); stn S1, Panglao Island, Biking, 9³5.3' N,

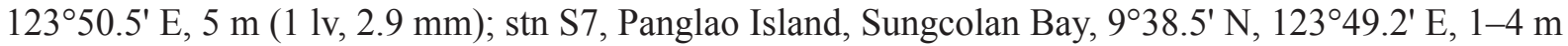
(3 lv, $2.8 \mathrm{~mm}, 3.2 \mathrm{~mm}, 3.2 \mathrm{~mm}$ ); stn S13, Bohol Island, Baclayon Takot, 9³7.1' N, 123⒌ $2.6^{\prime} \mathrm{E}$, 8-15 m (1 lv, $2.7 \mathrm{~mm}$ ); stn S14, Pamilacan Island, 9²9.3' N, 123⒌ 55.1' E, 5-12 m (1 lv, $3.1 \mathrm{~mm})$; stn S16, Panglao Island, Bingag, 9³7.6' N 12347.3' E, 15-18 m (1 lv, $3.0 \mathrm{~mm})$.

INDONESIA: Togian Islands: stn Tog13, Batudaka Island, 0²9.8' S, 121 ${ }^{\circ} 36.9^{\prime} \mathrm{E}, 36-39 \mathrm{~m}$ (1 dd, 3.6 mm; PS-020554); stn Tog14, Batudaka Island, 0²9.8' S, 12136.9' E, 21-25 m (1 dd); stn Tog22, Batudaka Island, $0^{\circ} 31.0^{\prime} \mathrm{S}, 121^{\circ} 37.1^{\prime} \mathrm{E}, 20-22 \mathrm{~m}$ (1 dd, SMF); stn Tog34, Pasir Tengah Atoll, 0²5.0' S, $121^{\circ} 38.9^{\prime}$ E, 23-26 m (1 dd, SMF).

PAPUA NEW GUINEA: KAVIENG 2014: stn KB04, NW point of Nusa Island, $2^{\circ} 33.9^{\prime} \mathrm{S}, 150^{\circ} 46.7^{\prime} \mathrm{E}$, $15-17 \mathrm{~m}$ (1 dd); stn KB08, E of N Cape, 2 $33.2^{\prime} \mathrm{S}, 150^{\circ} 48.2^{\prime} \mathrm{E}, 13 \mathrm{~m}$ (3 dd); stn KB16, between Big Nusa and Little Nusa, $2^{\circ} 34.6^{\prime}$ S, $150^{\circ} 46.3^{\prime}$ E, 13-14 m (2 dd); stn KB26, entrance of Albatross Passage, $2^{\circ} 44.6^{\prime} \mathrm{S}, 150^{\circ} 43^{\prime} \mathrm{E}, 9-15 \mathrm{~m}$ (3 dd); stn KB28, S side of Baudisson Island, $2^{\circ} 43.7^{\prime} \mathrm{S}, 150^{\circ} 38.4^{\prime} \mathrm{E}, 15-26 \mathrm{~m}$ $(1 \mathrm{dd})$; stn KB36, N side of Wadei Island, $2^{\circ} 38.8^{\prime} \mathrm{S}, 150^{\circ} 38.4^{\prime} \mathrm{E}, 3-8 \mathrm{~m}(1 \mathrm{lv})$; stn KB38, S side of Patio Island, $2^{\circ} 36.2^{\prime} \mathrm{S}, 150^{\circ} 31.6^{\prime} \mathrm{E}, 6-8 \mathrm{~m}(4 \mathrm{lv})$; stn KB58, N point of Nusalomon Island, $2^{\circ} 34.1^{\prime} \mathrm{S}$, $150^{\circ} 37.5^{\prime}$ E, $12 \mathrm{~m}$ (3 lv); stn KB64, New Ireland mainland, N coast, $2^{\circ} 33.5^{\prime} \mathrm{S}, 150^{\circ} 48.8^{\prime} \mathrm{E}, 19 \mathrm{~m}(1 \mathrm{dd})$; stn KPS09, Baudisson Island, $2^{\circ} 41.6^{\prime} \mathrm{S}, 150^{\circ} 37.2^{\prime} \mathrm{E}, 18-27 \mathrm{~m}$ (2 dd, $3.3 \mathrm{~mm}, 3.4 \mathrm{~mm}$; PS-020555); stn KPS10, Baudisson Island, 2०41.6' S, 150 $37.2^{\prime} \mathrm{E}, 12-14 \mathrm{~m}$ (3 dd, $\left.2.7 \mathrm{~mm}, 2.8 \mathrm{~mm}, 3.5 \mathrm{~mm}\right)$; stn KPS11, Lemus Island, 2³8.3' S, 150 ${ }^{\circ} 37.4^{\prime}$ E, 8-19 m (2 dd, 2.5 mm, 2.9 mm); stn KS09, W of Nago Island, $2^{\circ} 36.1^{\prime} \mathrm{S}, 150^{\circ} 45.9^{\prime} \mathrm{E}, 15-16 \mathrm{~m}$ (2 dd); stn KS33, E of Nusaum Island, 2³8.2' S, $150^{\circ} 38.7^{\prime} \mathrm{E}$, 8-10 m (2 lv); stn KS51, E side of Anelaua Island, 2 ${ }^{\circ} 35.2^{\prime} \mathrm{S}, 150^{\circ} 30.5^{\prime} \mathrm{E}, 2-4 \mathrm{~m}$ (1 dd).

MARSHALL ISLANDS: Kwajalein Atoll, ocean side of reef, shell grit, 70 feet, leg. W. Blacketer, 2007 (1 dd, 3.3 mm; PS-020491).

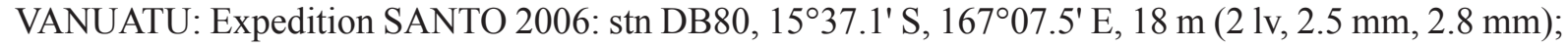

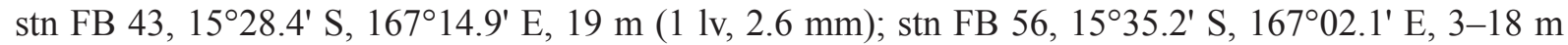

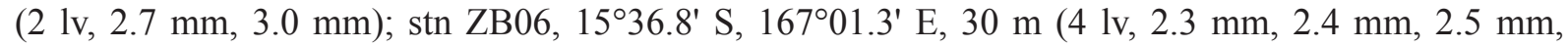

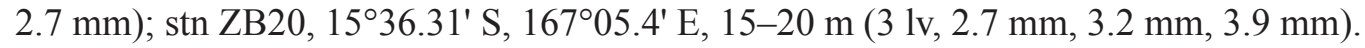


NEWCALEDONIA:ExpeditionMONTROUZIER:SecteurdeKoumac, $\operatorname{stn} 1319,20^{\circ} 44.7^{\prime} \mathrm{S}, 1^{\circ} 4^{\circ} 15.5^{\prime} \mathrm{E}$, 15-20 m (1 lv, 3.6 mm - Figs 2D, 3B-C); Secteur de Koumac, stn 1357, 20³0.2' S, 166² 26.4' E, 25-35 m (1 lv, $3.3 \mathrm{~mm}$ ); Secteur de Nouméa, stn 1318, 2041.4' S, 164¹4.8' E, 20-30 m (1 lv, $3.6 \mathrm{~mm})$.

LOYALTY ISLANDS: Lifou, Baie du Santal, Atelier LIFOU 2000: stn 1423, 20 54.0' S, $167^{\circ} 07.3^{\prime} \mathrm{E}$,

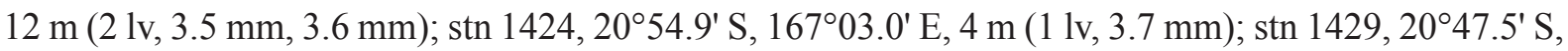
$167^{\circ} 07.1^{\prime} \mathrm{E}, 8-18 \mathrm{~m}(2 \mathrm{lv}, 3.3 \mathrm{~mm}, 4.4 \mathrm{~mm}$ - Fig. $2 \mathrm{C})$; stn 1432 , $20^{\circ} 53.5^{\prime} \mathrm{S}, 167^{\circ} 02.7^{\prime} \mathrm{E}, 8-18 \mathrm{~m}(1 \mathrm{lv}$, $3.2 \mathrm{~mm})$; stn $1436,20^{\circ} 55.5^{\prime} \mathrm{S}, 167^{\circ} 04.2^{\prime} \mathrm{E}, 10-20 \mathrm{~m}(1 \mathrm{lv}, 3.6 \mathrm{~mm})$; stn $1457,20^{\circ} 46.8^{\prime} \mathrm{S}, 167^{\circ} 02.75^{\prime} \mathrm{E}$, 5-10 m (1 lv, $3.1 \mathrm{~mm})$.

FIJI: MUSORSTOM 10: stn CP1334, 1651' S, 178²14' E, 251-257 m (1 dd, 4.8 mm).

\section{Description}

SHELl. Very small (3.0-4.5 mm), ovate to fusiform (b/h $0.47-0.5 ; 1 \mathrm{w} / \mathrm{h} 0.65-0.67 ; \mathrm{a} / \mathrm{h} 0.48-0.5)$, pointed at its tip. Teleoconch usually of 3-3.5, up to 5 whorls. Suture incised, undulating. Early $1-1.5$ teleoconch whorls almost cylindrical, with distinct shoulder; later whorls strongly convex in outline, with narrower concave subsutural ramp delineating adjacent whorls. Sculpture of strong and wide rounded axial ribs (10 on last whorl), well pronounced on whorls periphery and vanishing adapically. Axial ribs overridden by evenly interspaced, low and rounded spiral cords with shallow interstices. Late spire whorls sculptured with three spiral cords, adapical one much weaker, than succeeding. Microsculpture of dense microtubercles covering entire teleoconch surface. Last adult whorl and shell base with 6-7 subequal spiral cords followed by 3-5 oblique rows of tubercles on fasciole. Siphonal canal stout, moderately long, notably notched at its tip. Aperture narrow, elongated, contorted due to strong denticles of outer lip directed inwards. Adapicalmost of four denticles strongest. Inner lip strong, with distinct varix. Anal sinus subsutural, rounded, moderately deep and slightly constricted by callous subsutural tubercle.

РвотосоNCh. White, conical, of 3.3-3.5 whorls, PI whorls evenly rounded with fine sculpture of spiral cords and weak axial riblets. Late $\sim 1.5$ whorls with slightly flattened subsutural area and convex periphery, sculptured with subsutural row of fine, evenly interspaced axial riblets and with somewhat "crumpled" diagonally cancellate sculpture on periphery. Protoconch-teleoconch transition distinct, with moderately deep subsutural notch.

CoLour. Background colour white, spire whorls with one row of large, oval, dark-olive spots encircled by a fine darker line, situated in interspaces between axial ribs above whorl periphery. Shell base with another row of dark olive spots and smaller regular spots on siphonal canal. Periphery of last adult whorl with bright yellow spiral line in interspace between third and fourth spiral cords, this line also visible on spire whorls, right above suture. Protoconch off-white.

RADULA. Small, of 7 transversal rows, consisting of narrowly triangular, pointed, marginal teeth, with slightly convex dorsal side (Fig. 4B-C). Tooth length 130-140 $\mu \mathrm{m}$ (about 7.3\% of aperture height), tooth width about $40 \mu \mathrm{m}$.

\section{Distribution and habitat}

Distributed throughout the Indo-Pacific from Mauritius and the Maldives to the Philippines, Guam, Marshall Islands, Indonesia, Papua New Guinea, Queensland, Vanuatu, New Caledonia and Fiji, in shallow water.

\section{Remarks}

Hemilienardia ocellata can be distinguished from other eyespot-patterned Hemilienardia species by the ovate outline of the teleoconch and a proportionally very large protoconch. Hemilienardia 


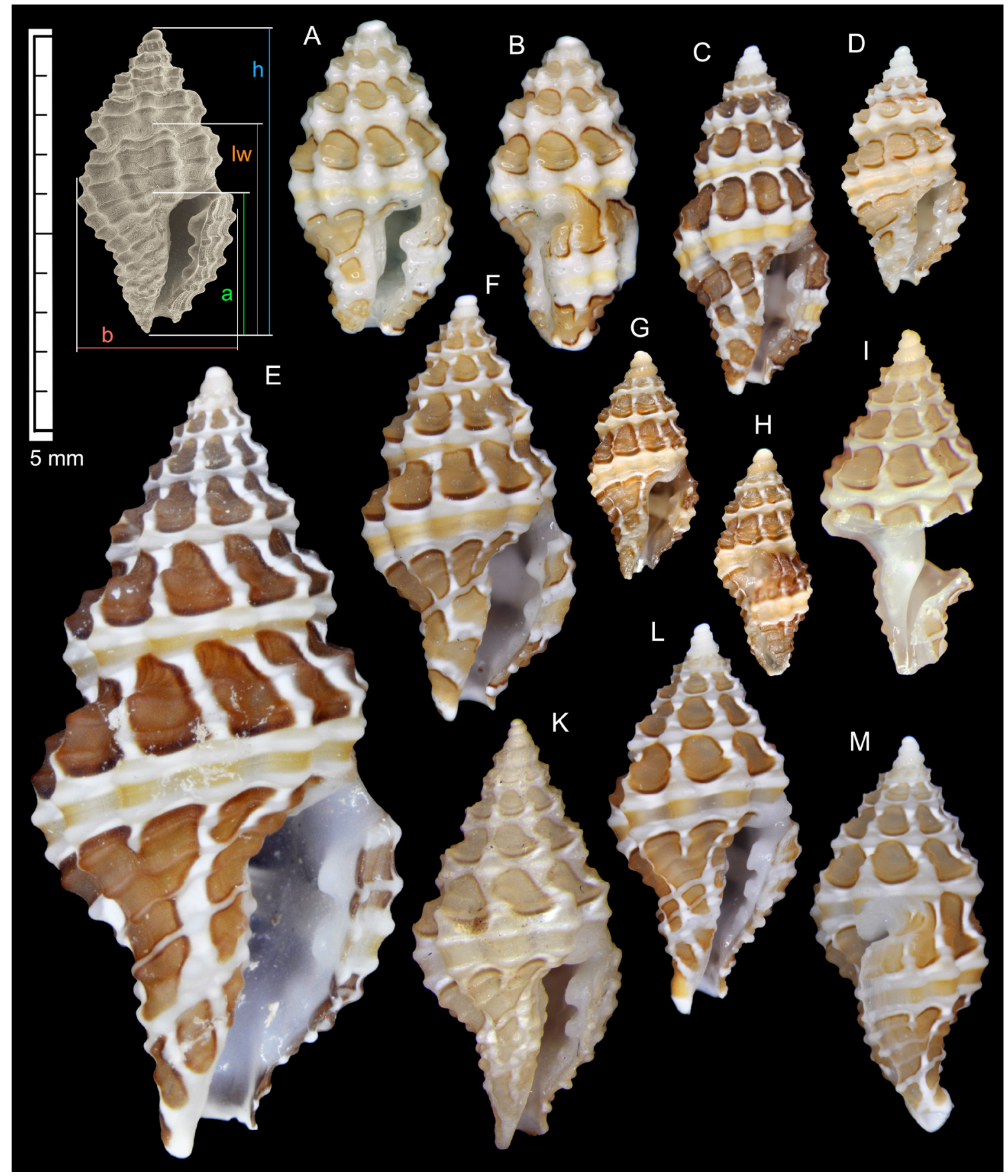

Fig. 2. Species of the Hemilienardia ocellata complex. The SEM image with no letter denoted shows standard measurements. A-D. Hemilienardia ocellata (Jousseaume, 1884). A-B. Syntype, MNHN IM-2000-3128, Mauritius, 4.0 mm. C. Loyalty Islands, Lifou, Baie du Santal, Atelier Lifou 2000, stn $1429,20^{\circ} 47.5^{\prime} \mathrm{S}, 167^{\circ} 07.1^{\prime} \mathrm{E}, 8-18 \mathrm{~m}, 4.4 \mathrm{~mm}$. D. New Caledonia, Secteur de Koumac, Expedition Montrouzier, stn 1319, 2044.7' S, $164^{\circ} 15.5^{\prime}$ E, 15-20 m, 3.6 mm. E-F. Hemilienardia acinonyx sp. nov. E. Holotype, MNHN IM-2013-33593, Philippines, $8.1 \mathrm{~mm}$. F. Loyalty Islands, Lifou, Baie du Santal, Atelier Lifou 2000, stn 1441, 2046.4' S, 16702.0' E, 20 m, 5.4 mm. G-H. Hemilienardia lynx sp. nov., holotype, MNHN IM-2013-5489, Papua New Guinea, 2.75 mm. I-M. Hemilienardia pardus sp. nov. I. BMOO 17147, Society Islands, Moorea. K. Holotype, MNHN IM-2000-31661, 5.8 mm. L-M. Loyalty Islands, Lifou, Baie du Santal, Atelier Lifou 2000, stn 1454, 2056.65' S, $167^{\circ} 02.0^{\prime}$ E, 15-18 m, $5.2 \mathrm{~mm}$. 
FEDOSOV A.E. et al., Species delimitation in Hemilienardia ocellata complex

lynx sp. nov. is undoubtedly the closest species in terms of size and shell shape. However, the two species differ in the number of protoconch whorls and the shape of the ocellae; these are ovate in $\mathrm{H}$. ocellata and more "squarish" in H. lynx sp. nov. Hemilienardia acinonyx sp. nov. differs from H. ocellata by its orthoconoid spire, smaller protoconch and larger adult size; in addition, specimens of $H$. acinonyx sp. nov. have a characteristic spiral thread in the interval between the third and fourth spiral cords, while the second spiral cord is often strongly pronounced, giving a somewhat shouldered appearance to the late teleoconch whorls. Finally, H. pardus sp. nov. may be easily separated from $H$. ocellata by its broad biconical shell with very narrow aperture and long siphonal canal.

Hemilienardia acinonyx sp. nov.

urn:1sid:zoobank.org:act:0B56D2CD-F00D-4749-9C62-0993A5C2B3F2

Figs 2E-F, 3D-E, 4C

\section{Etymology}

The epithet refers to the genus Acinonyx (family Felidae) and its graceful member, the cheetah. Used as a noun in apposition.

\section{Type material}

Holotype

PHILIPPINES: Panglao Island, off Momo Beach, lumun-lumun net, 60-80 m (lv, $8.1 \mathrm{~mm}$ - Fig. 2E) (MNHN IM-2013-33593).

\section{Paratypes}

PHILIPPINES: paratype 1, same locality as holotype (lv, $5.5 \mathrm{~mm}$ ) (MNHN IM-2013-33592); paratype 2, same locality as holotype (lv, 7,6 mm) (MNHN IM-2013-33594); paratype 3, Balicasag Island, lumunlumun net, 70-80 m (lv, $7.0 \mathrm{~mm})$ (PS-020556).

\section{Other material examined}

PAPUA NEW GUINEA: KAVIENG 2014, stn KB20, S coast of Baudisson Island, $2^{\circ} 45.2^{\prime} \mathrm{S}, 150^{\circ} 41.7^{\prime} \mathrm{E}$, $8 \mathrm{~m}(1 \mathrm{dd}, 6.8 \mathrm{~mm})$.

LOYALTY ISLANDS: Lifou, Atelier LIFOU 2000: stn 1441, Baie du Santal, 2046.4' S, $167^{\circ} 02.0^{\prime} \mathrm{E}$,

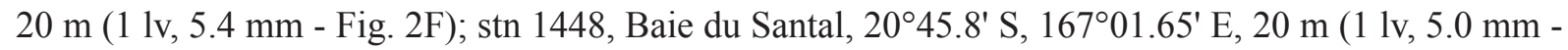
Fig. 3D-E).

PHILIPPINES: same locality as holotype (juveniles, 4 lv, $2.9 \mathrm{~mm}, 2.8 \mathrm{~mm}, 2.7 \mathrm{~mm}, 2.5 \mathrm{~mm}$ ).

NEW CALEDONIA: LAGON Secteur de Poindimié, stn DW 830, 2049' S, 165¹9' E, 105-110 m (1 $\mathrm{dd}, 3.3 \mathrm{~mm}$ ).

FIJI: MUSORSTOM 10, stn CP1363, 18²12' S, 178 $33^{\prime}$ E, 144-150 m (1 dd, 4.4 mm).

\section{Description}

SHELL. Small, broadly fusiform to biconical (b/h 0.47 ; $1 \mathrm{w} / \mathrm{h} 0.67-0.69$; a $/ \mathrm{h} 0.48-0.5$ ), with rather long and slightly recurved siphonal canal. Spire orthoconoid, teleoconch of 3.5-5 whorls. Suture incised, undulating. Adapical portion of teleoconch whorls forming wide concave depression, basal portion strongly convex, with periphery shifted towards lower suture. Sculpture of very strong, widely interspaced axial ribs (9-10 on last whorl), vanishing on adapical areas of whorls. Axial ribs overridden by rounded spiral cords, slightly thickened where intersecting axials. Interspaces shallow. Microsculpture of dense tubercles covering entire teleoconch surface and fine arcuate growth lines in adapical depression. Spire 
whorls sculptured with three spiral cords, adapical one weaker, than two succeeding; second spiral cord strongly elevated, giving spire whorls indistinctly shouldered appearance. Last adult whorl with 6 major spiral cords, and distinct thread situated in interspace between third and fourth major cords. Siphonal canal long, recurved abaxially, deeply notched at its tip, sculptured with oblique rows of tubercles. Aperture elongate, slightly contorted. Outer apertural lip with moderately developed varix, its inside with four denticles, of which the adapicalmost is strongest. Inner lip contorted below its mid-height, with oblique cords sculpturing fasciole, continuing inside aperture. Anal sinus rounded, deep and rather narrow, slightly constricted by subsutural callous tubercle.

Protoconch. White, narrowly conical, of 2.3 evenly convex whorls. PI whorls with sharp spiral cords on its abapical portion, intersected by short axial strokes to form elevated, cross-shaped tubercles. PII sculptured with subsutural row of fine, evenly spaced, axial riblets and bearing somewhat "crumpled" diagonally cancellate sculpture on periphery.

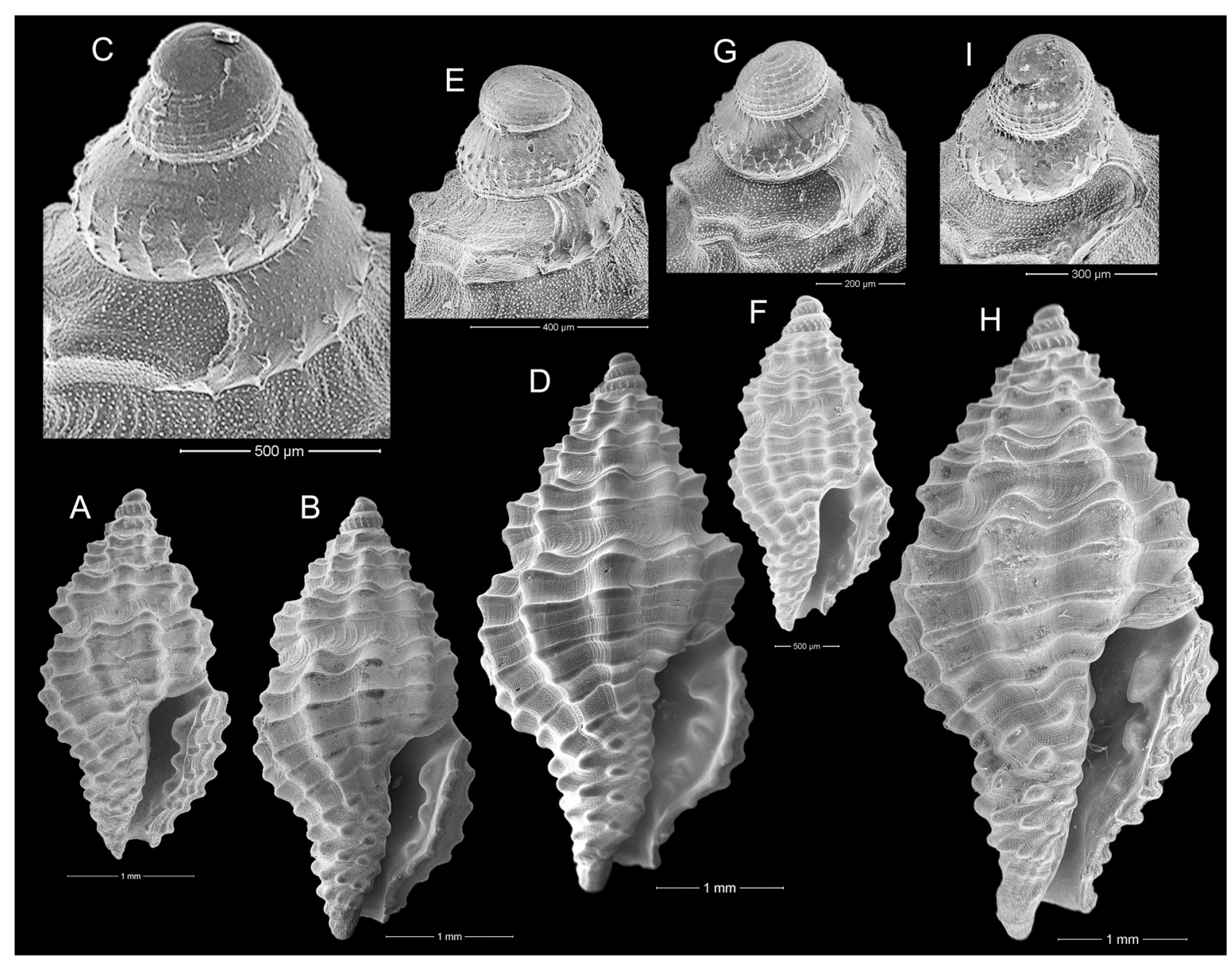

Fig. 3. Protoconch and shell morphology in the Hemilienardia ocellata complex. A-C. H. ocellata (Jousseaume, 1884). A. Specimen from the Maldives, Ari Atoll, Maagau Kandu, 25 m, $3.1 \mathrm{~mm}$ long. B-C. Specimen from New Caledonia, Expedition MONTROUZIER, stn 1319, 2044.7' S, 164 $15.5^{\prime}$ E, 15-20 m, $3.6 \mathrm{~mm}$ long. D-E. H. acinonyx sp. nov. Specimen from the Loyalty Islands, Lifou, Baie du Santal, Atelier Lifou 2000, stn 1448, 2045.8' S, 16701.65' E, 20 m, 5.0 mm long. F-G. H. lynx sp. nov. Holotype, MNHN IM-2013-5489, Madang District, off Kranket Island, PAPUA NIUGINI stn PP14, $05^{\circ} 12^{\prime} \mathrm{S}, 145^{\circ} 50^{\prime} \mathrm{E}, 100-120 \mathrm{~m}, 2.75 \mathrm{~mm}$ long. H-I. H. pardus sp. nov. Specimen from the Loyalty Islands, Lifou, Baie du Santal, Atelier LIFOU 2000, stn 1454, 2056.65' S, $167^{\circ} 02.0^{\prime} \mathrm{E}, 15-18 \mathrm{~m}, 5.2$ mm long. 
CoLour. Background colour white with yellow line in interspace between third and fourth spiral cords, and regular triangular or squarish olive blotches encircled by darker line, situated above third spiral cord in interspaces between axial folds. Similar blotches covering shell base and siphonal canal.

RADULA. Very small, consisting of less than 10 rows of marginal teeth that are triangular, flat, with slightly thickened margins (Fig. 4D). Tooth width about $24 \mu \mathrm{m}$, length about $35 \mu \mathrm{m}$ (about $1.5 \%$ of aperture height).

Dimensions. Holotype $8.1 \times 3.8 \mathrm{~mm}$.

\section{Distribution and habitat}

Recorded from the Philippines, Papua New Guinea, New Caledonia and Fiji, living at depths of 20-70 m.

\section{Remarks}

Hemilienardia acinonyx sp. nov. can be distinguished from other eye-spotted species of Hemilienardia by its orthoconoid spire with rather small protoconch, and the presence of the diagnostic spiral thread in the interspace between the third and fourth spiral cords. The ocellae decorating shell of $H$. acinonyx sp. nov. are usually triangular or squarish, which easily tells it apart from the more common $H$. ocellata. Specimens of $H$. acinonyx sp. nov. from the type locality notably exceed other ocellated species of Hemilienardia in size, as they may reach a height of 10-12 $\mathrm{mm}$. Besides, the radula teeth in studied specimens of $H$. acinonyx sp. nov. are about three times shorter compared to the marginals of H. ocellata, and are flattened, broadly triangular in shape.

\section{Hemilienardia lynx sp. nov. urn:1sid:zoobank.org:act:9DCEA5F7-1759-4DDA-A37B-97558D2D7F12} Figs $2 \mathrm{G}-\mathrm{H}, 3 \mathrm{~F}-\mathrm{G}$

\section{Etymology}

The epithet of this species refers to a smaller spotted cat, the lynx. Used as a noun in apposition.

\section{Type material}

\section{Holotype}

PAPUA NEW GUINEA: PAPUA NIUGINI 2012 stn PP 14, Bismarck Sea, Madang District, off Kranket Island, 5¹2' S, 14550' E, 100-120 m (lv, 2.75 mm - Figs 2G-H, 3F-G) (MNHN IM-2013-5489).

Other material examined (Hemilienardia cf. lynx)

PHILIPPINES: PANGLAO 2004: stns L69-73, Balicasag Island, 9³0.7' N, 12340.9' E, 90-98 m (1 dd); stn 76, off Momo Beach, 9³6.5' N, 1234‥' E, ca 80 m (1 lv, 2 dd; 1 dd, PS-020572).

\section{Description}

SHELL. Very small, ovate to fusiform (b/h $0.49 ; 1 \mathrm{w} / \mathrm{h} 0.67$; a/h 0.5$)$, pointed at its tip. Teleoconch of 3.2 whorls. Suture incised, undulating. Early 1-1.5 teleoconch whorls almost cylindrical, with distinct shoulder; later whorls strongly convex in outline, with narrower concave subsutural ramp, delineating adjacent whorls. Sculpture of strong, wide and rounded axial ribs (10 per whorl), well pronounced on periphery of whorls and vanishing adapically. Axial ribs overridden by evenly spaced, low and rounded spiral cords with shallow interspaces. Late spire whorls sculptured with three spiral cords, adapical one much weaker, than succeeding. Microsculpture of dense micro-tubercles covering entire teleoconch surface. Last adult whorl and shell base with 8 subequal spiral cords followed by 3 oblique rows of 
tubercles on fasciole. Siphonal canal stout, moderately long, notably notched at its tip. Aperture narrow, elongated, with four denticles, the adapicalmost strongest. Outer lip strong, with distinct varix. Anal sinus rounded, moderately deep and slightly constricted by callous subsutural tubercle.

Protoconch. Conical, of slightly less than 3.0 whorls, PI white, evenly rounded with fine sculpture of spiral cords and weak axial riblets. Late $\sim 1.5$ PII whorls light brown, with slightly flattened subsutural area and convex periphery, sculptured with subsutural row of fine evenly spaced axial riblets and with diagonally cancellate sculpture on periphery. Protoconch-teleoconch transition distinct, with moderately deep subsutural notch.

CoLour. Background colour white, spire whorls with one row of large, oval, dark-olive squarish blotches encircled by a fine and slightly darker line, situated in interspaces between axial ribs above whorl periphery. Shell base with another row of dark olive blotches reaching tip of siphonal canal. Periphery of last whorl with a yellow spiral line in interspace between third and fourth spiral cords; this line can also be seen on spire whorls, right above the suture.

Radula. No data.

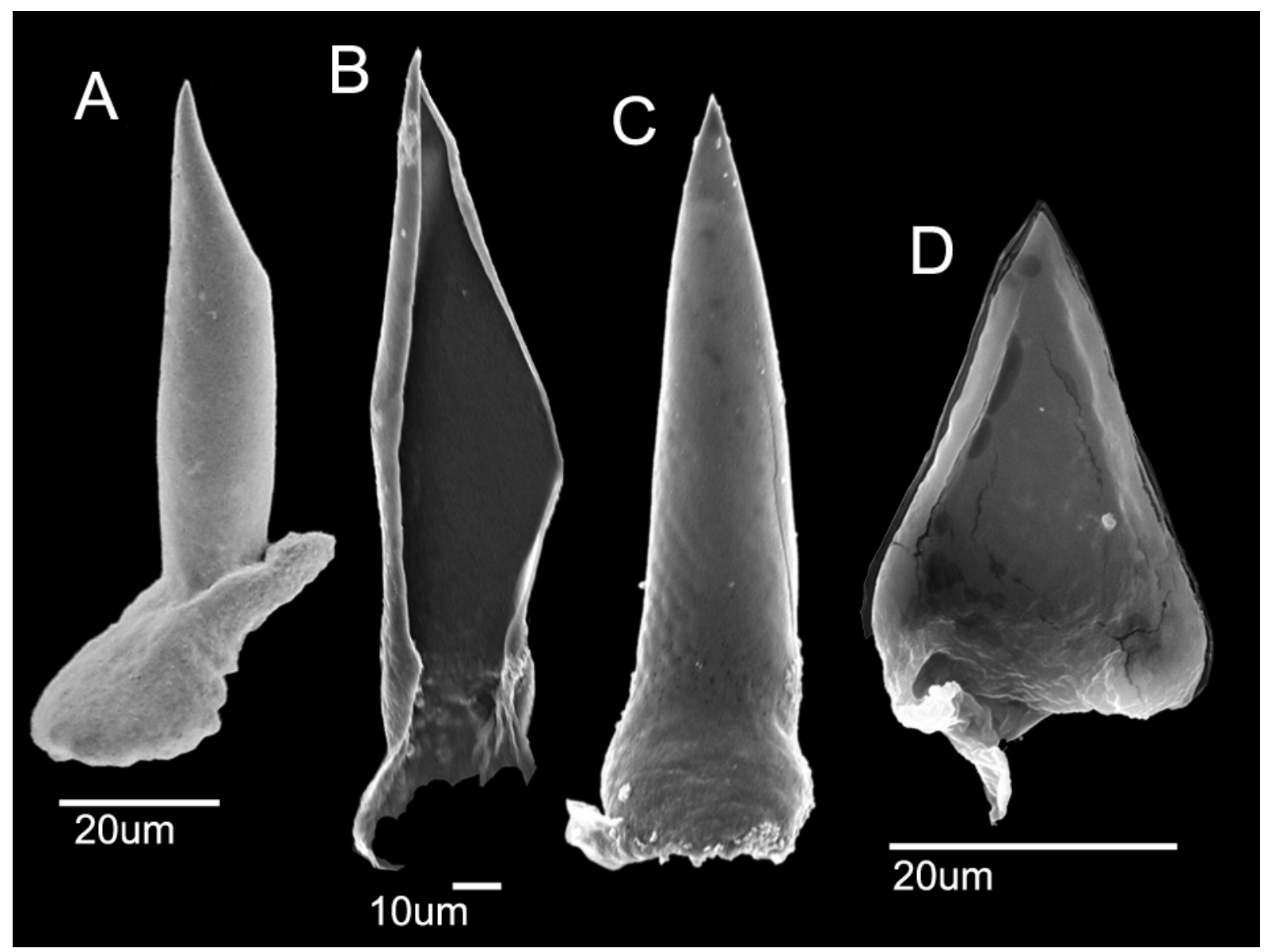

Fig. 4. Marginal radular teeth of some species of Hemilienardia. A. H. malleti (Récluz, 1852) (from Kantor \& Taylor 2002). B-C. H. ocellata (Jousseaume, 1884). Specimen from the Loyalty Islands, Lifou, Baie du Santal, Atelier LIFOU 2000, stn 1429, 2047.5' S, $167^{\circ} 07.1^{\prime}$ E, 8-18 m, 4.4 mm long. D. H. acinonyx sp. nov. Specimen from the Loyalty Islands, Lifou, Baie du Santal, Atelier LIFOU 2000, stn $1448,20^{\circ} 45.8^{\prime} \mathrm{S}, 167^{\circ} 01.65^{\prime} \mathrm{E}, 20 \mathrm{~m}, 5.0 \mathrm{~mm}$ long. 
DiMENSIONS. $2.75 \times 1.35 \mathrm{~mm}$.

\section{Distribution and habitat}

Papua New Guinea, Bismarck Sea, off Madang, 100-120 m; possibly Central Philippines, Balicasag Island, $80 \mathrm{~m}$.

\section{Remarks}

This small ocellate Hemilienardia species is closest to H. ocellata in dimensions and shell shape. However, $H$. lynx sp. nov. can be distinguished from $H$. ocellata by the smaller and slightly shorter protoconch, the less narrow aperture, the less convex teleoconch whorls and the larger and more squarish ocellae. The holotype of $H$. lynx sp. nov. has an adult apertural morphology and appears to be mature. At $2.75 \mathrm{~mm}$, it seems to be the smallest ocellate Hemilienardia species, notably smaller, than the otherwise similar $H$. acinonyx sp. nov. Based on the preliminary records of $H$. lynx sp. nov. from the Philippines, it does co-occur there with H. acinonyx sp. nov., and the two species were sampled together from deep lumunlumun nets. The two species are identical regarding coloration; however, specimens of $H$. acinonyx sp. nov. of a shell size below $8 \mathrm{~mm}$ retain a thin and fragile juvenile outer lip, whereas specimens of $H$. lynx sp. nov. display an adult morphology of the aperture, although their size does not exceed $3 \mathrm{~mm}$. The other character allowing separation of these two species is the shell shape, being rather fusiform in H. lynx sp. nov. and biconical with an orthoconoid spire in H. acinonyx sp. nov.

Hemilienardia pardus sp. nov. urn:1sid:zoobank.org:act:CD765DA2-C2D6-4449-BF85-6DB9C2C8C173

Figs 2I-M, 3H-I

Hemilienardia cf. ocellata - Tröndlé \& Boutet 2009: 39.

\section{Etymology}

The species epithet refers to a well known spotted cat, the leopard. Used as a noun in apposition.

\section{Type material}

\section{Holotype}

SOCIETY ISLANDS: Tahiti, faille d'Arue, 20 m (1 dd, 5.8 mm - Fig. 2K) (MNHN IM-2000-31661).

\section{Paratypes}

SOCIETY ISLANDS: paratype 1, Tahiti, faille d'Arue, Mateval Bay, in front of Radisson Hotel, $20 \mathrm{~m}$ (1 dd, $5.4 \mathrm{~mm}$ ) (MNHN IM-2000-31662); paratype 2, Moorea, off Motu Ahi, 17³3.15' S, 14946.41' W, 73 m, deep reef slope (1 lv, $4.05 \mathrm{~mm}$ - Fig. 2I) (UF4565454, sequenced as BMOO 17147).

\section{Other material examined}

LOYALTY ISLANDS: Lifou, Baie du Santal, Atelier LIFOU 2000, stn 1434, 2052.5' S, $167^{\circ} 08.1^{\prime}$ E,

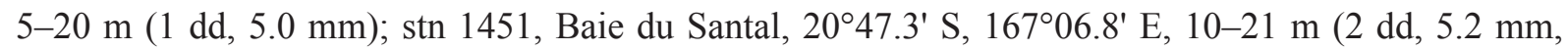
$4.8 \mathrm{~mm}$ ); stn $1454,20^{\circ} 56.65^{\prime} \mathrm{S}, 167^{\circ} 02.0^{\prime} \mathrm{E}, 15-18 \mathrm{~m}$ (1 lv, $5.2 \mathrm{~mm}$ - Figs $\left.2 \mathrm{~L}-\mathrm{M}, 3 \mathrm{H}-\mathrm{I}\right)$.

NEW CALEDONIA: Touho, Récif man, Expedition MONTROUZIER, stn 1269, 20³5.1' S, $165^{\circ} 08.1^{\prime} \mathrm{E}$, $15-20 \mathrm{~m}(1 \mathrm{lv}, 5.6 \mathrm{~mm})$.

\section{Description}

SHELL. Small, widely biconical (b/h $0.5 ; 1 \mathrm{w} / \mathrm{h} 0.71 ; \mathrm{a} / \mathrm{h} 0.51)$, with rather low spire and very long recurved siphonal canal. Teleoconch of 4.5 whorls; early $1-1.5$ spire whorls distinctly shouldered, with angulate outline, later with concave subsutural depression and convex below; periphery shifted abapically. Suture 
indistinct. Axial sculpture of strong and wide rounded axial ribs ( 8 on last whorl), best pronounced at whorl periphery and indistinct in subsutural ramp. Axial folds overridden by spiral cords, slightly widened where intersecting axials. Microsculpture of dense tubercles covering entire teleoconch surface. Spire whorls with three spiral cords below subsutural ramp. Adapical cord weaker than two succeeding ones, abapical spiral cord, marking whorl periphery, strongest. Peripheral cord bordered by suture of succeeding whorl. Last adult whorl and shell base with 8 spiral cords, adapical and abapical slightly weaker, than others. Siphonal canal long, recurved abaxially and slightly widened and notched at its tip. Fasciole sculptured with three distinct, oblique, gemmate cords. Aperture very narrow. Outer lip thick, with strong varix; inside of outer lip with three very strong, broad denticles with flattened crests, adapicalmost strongest. Inner lip recurved abaxially below mid-height, with three indistinct rounded plicae facing denticles of outer lip. Anal sinus rounded, deep and narrow, constricted by callous tubercle.

Protoconch. White, narrowly conical, of about 3 whorls. PI evenly rounded, with fine sculpture of spiral cords and weak axial riblets. Late $\sim 1.5$ PII whorls with slightly flattened subsutural area and convex periphery, sculptured with subsutural row of fine, evenly spaced axial riblets and with somewhat "crumpled" diagonally cancellate sculpture on periphery. Protoconch-teleoconch transition distinct, with moderately deep subsutural notch.

Colour. Background colour white, spire whorls with regular, ovate, dark-olive spots encircled by a fine darker line in interspaces between axial ribs above whorl periphery. Shell base and siphonal canal with similar blotches, though less regular, often merged together. Periphery of last adult whorls with bright yellow spiral line in interspace between third and fourth spiral cords.

Radula. No data.

Dimensions. Holotype $5.8 \times 2.85 \mathrm{~mm}$.

\section{Distribution and habitat}

Known from the Society Islands, living at a depth of $73 \mathrm{~m}$, and from the Loyalty Islands and New Caledonia, living at depths of 15-20 m (Fig. 5).

\section{Remarks}

Even though there are no molecular data available for H. pardus sp. nov. from New Caledonia and the Loyalty Islands, we assume that it is conspecific with specimens from the Society Islands based on shell characters. This species can easily be distinguished from other members of this group by its widely biconical shell, with a very long and recurved siphonal canal and proportionally low spire. Apart from that, $H$. pardus sp. nov. is characterized by having only eight axial ribs on the last adult whorl, while there are typically ten in $H$. ocellata and $H$. acinonyx sp. nov.

\section{Discussion}

Despite the fact that the recognition of species in the Hemilienardia ocellata complex is complicated by the shared ocellate colour pattern, they demonstrate stable differences in shell morphology, which become clear in SEM images. Moreover, the material shows notable differences in size and number of whorls of the protoconch. The latter character is known to vary notably among closely related conoidean species (Bouchet 1990; Puillandre et al. 2010), and particularly in the family Raphitomidae (Fedosov \& Puillandre 2012; Fedosov \& Stahlschmidt 2014). Thus, the species treated in the present study are not cryptic. Their ranges overlap in the western Pacific (the Philippines, Papua New Guinea, New Caledonia, Fiji), but there is evidence of distinct bathymetrical preferences: while $H$. ocellata occurs in shallow water, from the intertidal to 20-25 meters, both $H$. acinonyx sp. nov. and H. lynx sp. nov. were sampled from greater depths, about 70-100 m. Hemilienardia ocellata, H. acinonyx sp. nov. and H. pardus sp. nov. all occur - but do not co-occur - in the Loyalty Islands at depths of 5-20 m. 
The continuous geographic range of Hemilienardia ocellata is still to be confirmed. Only specimens from the Bismarck Sea were sequenced for COI, and low inferred genetic distances cannot be extrapolated to broader geographic scales. On the contrary, there is a clear, although rather weak, genetic structuring in $H$. ocellata revealed in the analysis of $16 \mathrm{~S}$ : specimens from Vanuatu form a distinct clade, separate from most sequenced specimens from the adjacent Bismarck Sea. Better geographic coverage in future studies may result in either a continuous range of genetic distances, where such differences between local populations will vanish, or in a set of separate clades corresponding to local, more or less distinctive, populations, depending likely on the presence of natural barriers decreasing the efficiency of dispersal. It should be noted that the protoconch of $H$. ocellata is notably larger, than in the other 'spotted cats', suggestive of the increased dispersal abilities of this species (Jablonski \& Lutz 1983). Nevertheless, the examination of specimens of $H$. ocellata from multiple localities from Mauritius and the Maldives to New Caledonia and Vanuatu revealed no consistent differences in shell morphology. Thus, if future work would demonstrate the existence of several molecular species referable to $H$. ocellata as circumscribed herein, this would truly be a case of cyptic species.

The Hemilienardia ocellata species complex is undoubtedly one of the most distinctive lineages among Conoidea. The purpose of their shell pattern remains unclear. Spotted colour patterns are common in the gastropod families Ovulidae and Eulimidae (Schiaparelli et al. 2005; Dgebuadze et al. 2012) and may be associated with their sedentary, symbiotic lifestyle; by adjusting shell and soft tissue colouration to their host species, ovulids and eulimids generate remarkable defensive camouflages or, on the contrary their ocellate mantle may be aposematic as is known in different lineages of nudibranchs, in particular chromodorids (Rudman 1991). These models, however, do not seem to apply to the 'spotted cat' raphitomids, as no conoideans are known to live symbiotic lifestyles. It is still likely, however, that the major role of the pattern is defense: visual recognition of the snails by predators may be hampered by the breaking of a recognizable shell outline into a set of separate bright blotches. Overall, owing to the minute size of many conoideans, very little is known about their biology and the spectrum of their

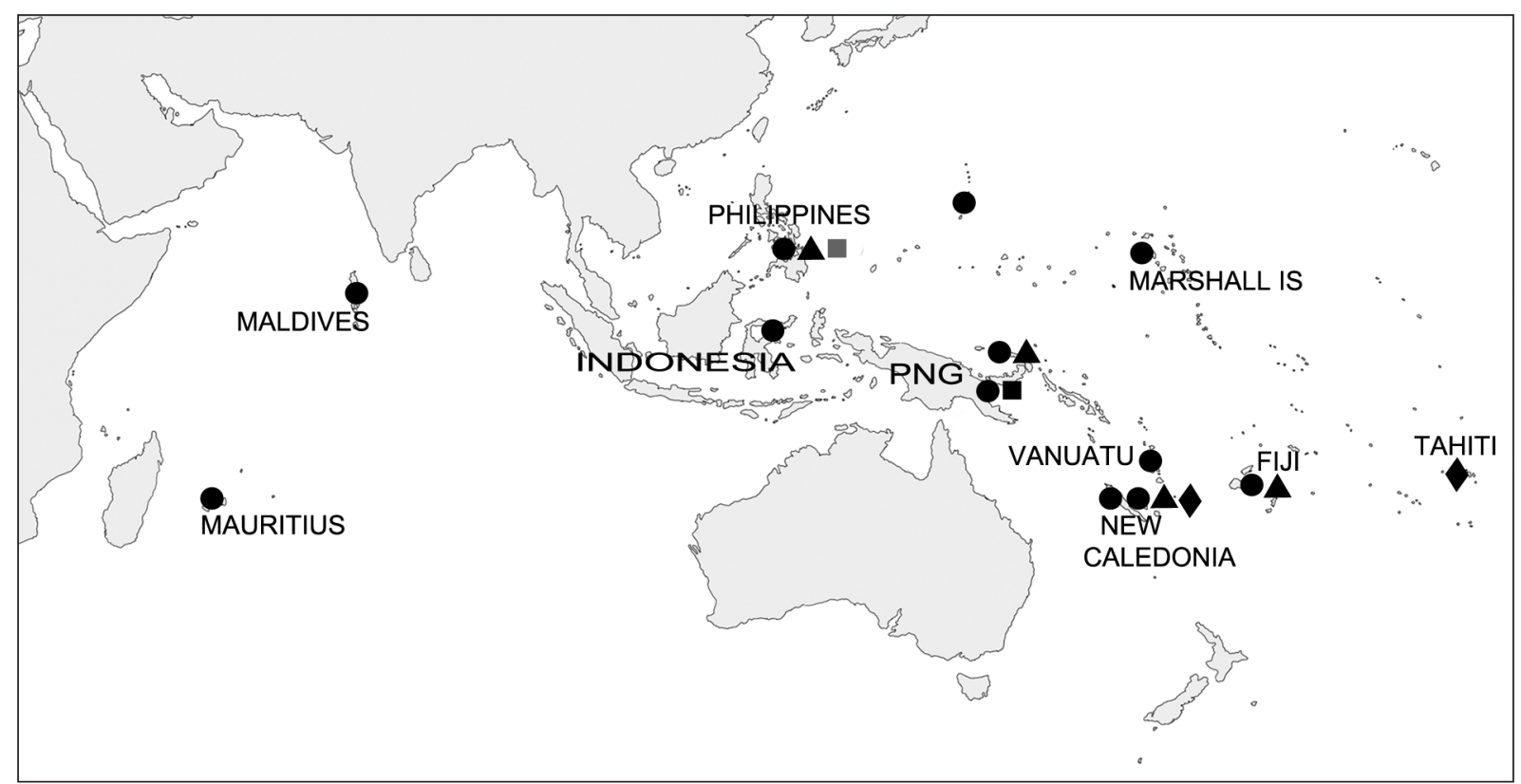

Fig. 5. Records of the Hemilienardia ocellata species complex, based on material examined in the present paper. Filled cycles $=H$. ocellata (Jousseaume, 1884); triangles $=H$. acinonyx sp. nov.; black square $=H$. lynx sp. nov.; grey square $=H$. cf. lynx sp. nov.; diamonds $=H$. pardus sp. nov. 
biological interactions, which would be a prerequisite to suggest reasonable hypotheses on the role of colour pattern for these molluses.

'Spotted cats' are distinctive not only because of their remarkable colour pattern: their flat or semienrolled radulae teeth are unique for the family Raphitomidae, all members of which that have been studied so far possess hypodermic teeth (Kantor \& Taylor 2002; Bouchet et al. 2011), excepting several species that were proven to be radula-less (Kantor \& Sysoev 1989; Kantor \& Taylor 2002; Fedosov 2007). According to Kantor \& Puillandre (2012), hypodermic marginal teeth are a key morphological determinant of the major conid conoidean clade, which comprises Borsoniidae, Conidae, Conorbidae, Clathurellidae, Mangeliidae, Mitromorphidae and Raphitomidae. Thus, the unusual morphology of marginals in the Hemilienardia ocellata complex is most likely a result of secondary simplification. This simplification of the radula is becoming further obvious from the relative dimensions of the radular teeth: whereas the marginal teeth attain about $7 \%$ of the aperture height in $\mathrm{H}$. ocellata, the marginals only reach $1.5 \%$ of the aperture height in $H$. acinonyx sp. nov. Semi-enrolled, simplified radular teeth were also found in some species of Mangelia (Bouchet et al. 2011), and the appearance of such teeth in Hemilienardia species can be attributed to the general tendency towards morphological simplification recorded in minute members of Raphitomidae and Mangeliidae (Kantor \& Taylor 2002).

\section{Acknowledgements}

Most molecular material in this paper originates from shore-based expeditions conducted by MNHN and Pro-Natura International as part of the Our Planet Reviewed programme. Funders and sponsors include the Total Foundation, the Prince Albert II of Monaco Foundation, the Stavros Niarchos Foundation, and the Richard Lounsbery Foundation. We are thankful to Gustav Paulay (FLMNH) and Chris Meyer (USNM), who provided sequences of the specimens BMOO 17147 and BMOO 10646 sampled in the course of the Moorea Biocode Project; and to Jean Letourneux (Tahiti), who contributed Hemilienardia specimens from the Society Islands, including the holotype of $H$. pardus sp. nov. We are thankful to Baldomero 'Toto' Olivera (University of Utah) for providing access to the lumun-lumun material sampled at Panglao Island in 2008. We also thank Yuri Kantor (IPEE RAS) for the radula preparation of Hemilienardia ocellata. We are also grateful to Catherine Rausch (SEM facility, MNHN) and Dr. Jiri Kucerik (University Landau) for their assistance while working with SEM and ESEM. The authors also thank Virginie Héros, Barbara Buge and Julien Brisset for their help in curating the specimens. This project was partly supported by the Service de Systématique Moléculaire (UMS 2700 CNRS-MNHN), by the CONOTAX project, funded by the French ANR (grant number ANR-13-JSV7-0013-01), and by a grant from the Russian Science Foundation (RSCF 16-14-10118).

\section{References}

Allen W.L., Cuthill I.C., Scott-Samuel N.E. \& Baddeley R. 2011. Why the leopard got its spots: relating pattern development to ecology in felids. Proceedings of the Royal Society, Series B 278: 1373-1380. http://dx.doi.org/10.1098/rspb.2010.1734

Bouchet P. 1990. Turrid genera and mode of development: the use and abuse of protoconch morphology. Malacologia 32: 69-77.

Bouchet P., Kantor Y.I., Sysoev A.V. \& Puillandre N. 2011. A new operational classification of the Conoidea (Gastropoda). Journal of Molluscan Studies 77: 273-308. http://dx.doi.org/10.1093/mollus/ eyr017

Bouchet P., Lozouet P., Maestrati P. \& Heros V. 2002. Assessing the magnitude of species richness in tropical marine environments: exceptionally high numbers of molluscs at a New Caledonia site. Biological Journal of the Linnean Society 75: 421-436. http://dx.doi.org/10.1046/j.1095-8312.2002.00052.x 
Dgebuadze P.Y., Fedosov A.E. \& Kantor Y.I. 2012. Host specificity of parasitic gastropods of the genus Annulobalcis Habe, 1965 (Mollusca, Gastropoda, Eulimidae) from crinoids in Vietnam, with descriptions of four new species. Zoosystema 34: 139-155. http://dx.doi.org/10.5252/z2012n1a6

Edgar R.C. 2004. MUSCLE: multiple sequence alignment with high accuracy and high throughput. Nucleic Acids Research 32: 1792-1797. http://dx.doi.org/10.1093/nar/gkh340

Fedosov A.E. 2007. Anatomy of accessory rhynchodeal organs of Veprecula vepratica and Tritonoturris subrissoides: new types of foregut morphology in Raphitominae (Conoidea). Ruthenica 17: 33-41.

Fedosov A.E. \& Puillandre N. 2012. Phylogeny and taxonomy of the Kermia-Pseudodaphnella (Mollusca: Gastropoda: Raphitomidae) genus complex: a remarkable radiation via diversification of larval development. Systematics and Biodiversity 10: 447-477. http://dx.doi.org/10.1080/14772000.20 12.753137

Fedosov A.E. \& Stahlschmidt P. 2014. Revision of the genus Thetidos Hedley, 1899 (Gastropoda: Conoidea: Raphitomidae) in the Indo-Pacific with descriptions of three new species. Molluscan Research 34: 258-273. http://dx.doi.org/10.1080/13235818.2014.909557

Folmer O., Black M., Hoeh W., Lutz R. \& Vrijenhoek R. 1994. DNA primers for amplification of mitochondrial cytochrome c oxidase subunit I from diverse metazoan invertebrates. Molecular Marine Biology and Biotechnology 3: 294-299.

Hall T.A. 1999. BioEdit: a user-friendly biological sequence alignment editor and analysis program for Windows 95/98/NT. Nucleic Acids Symposium Series 41: 95-98.

Hedley C. 1922. A revision of the Australian Turridae. Records of the Australian Museum 13: 231-359.

Héros V., Lozouet P., Maestrati P., Cosel R. von, Brabant D. \& Bouchet P. 2007. Mollusca of New Caledonia. In: Payri C. \& Richer de Forges B. (eds) Compendium of Marine Species from New Caledonia, ed. 2: 199-254. Documents Scientifiques et Techniques, IRD Nouméa II7.

Huelsenbeck J.P., Ronquist F. \& Hall B. 2001. MrBayes: bayesian inference of phylogeny. Bioinformatics 17: 754-755. http://dx.doi.org/10.1093/bioinformatics/17.8.754

Jablonski D. \& Lutz R.A. 1983. Larval ecology of marine benthic invertebrates: Paleobiological implications. Biological Reviews 58: 21-89.

Jousseaume F.P. 1884. Description de mollusques noveaux. Bulletin de la Société Zoologique de France 9: 169-192.

Kantor Y.I. \& Puillandre N. 2012. Evolution of the radular apparatus in Conoidea (Gastropoda: Neogastropoda) as inferred from a molecular phylogeny. Malacologia 55: 55-90. http://dx.doi. org/10.4002/040.055.0105

Kantor Y.I. \& Sysoev A.V. 1989. The morphology of toxoglossan gastropods lacking a radula, with a description of a new species and genus of Turridae. Journal of Molluscan Studies 55: 537-550. http:// dx.doi.org/10.1093/mollus/55.4.537

Kantor Y.I. \& Taylor J.D. 2002. Foregut anatomy and relationships of raphitomine gastropods (Gastropoda: Conoidea: Raphitominae). Bollettino Malacologico, Suppl. 4: 83-110.

Loch I. 1992. Lienardia. Australia Shell News 80: 2-3.

Palumbi S. 1996. Nucleic Acids II: the polymerase chain reaction. In: Hillis D., Moritz C. \& Mable B.K. (eds) Molecular Systematics: 205-247. Sinauer Associates, Sunderland, Massachusetts.

Powell A.W.B. 1966. The molluscan families Speightiidae and Turridae. Bulletin of the Auckland Institute and Museum 5: 1-184. 
Puillandre N., Baylac M., Boisselier M.C., Cruaud C. \& Samadi S. 2009. An integrative approach to species delimitation in Benthomangelia (Mollusca: Conoidea). Biological Journal of the Linnean Society 96: 696-708. http://dx.doi.org/10.1111/j.1095-8312.2008.01143.x

Puillandre N., Modica M.V., Zhang Y., Sirovich L., Boisselier M.C., Cruaud C., Holford M. \& Samadi S. 2012. Large scale species delimitation method for hyperdiverse groups. Molecular Ecology 21: 26712691. http://dx.doi.org/10.1111/j.1365-294X.2012.05559.x

Puillandre N., Sysoev A.V., Olivera B.M., Couloux A. \& Bouchet P. 2010. Loss of planktotrophy and speciation: geographical fragmentation in the deep-water gastropod genus Bathytoma (Gastropoda, Conoidea) in the western Pacific. Systematics and Biodiversity 8: 371-394. http://dx.doi. org/10.1080/14772001003748709

Rambaut A., Suchard M.A., Xie D. \& Drummond A.J. 2014. Tracer v. 1.4. Available from http://beast. bio.ed.ac.uk/Tracer [accessed 15 Nov. 2016].

Rudman W.B. 1991. Purpose in pattern: the evolution of colour in chromodorid nudibranchs. Journal of Molluscan Studies 57 (Suppl. 4): 5-21. http://dx.doi.org/10.1093/mollus/57.Supplement_Part_4.5

Schiaparelli S., Barucca M., Olmo E., Boyer M. \& Canapa A. 2005. Phylogenetic relationships within Ovulidae (Gastropoda: Cypraeoidea) based on molecular data from the 16S rRNA gene. Marine Biology 147: 411-420. http://dx.doi.org/10.1007/s00227-005-1566-0

Seronay R.A., Fedosov A.E., Astilla M.A., Watkins M., Saguil N., Heralde F.M., Tagaro S., Poppe G.T., Alino P.M., Oliverio M., Kantor Y.I., Concepcion G.P. \& Olivera B.M. 2010. Accessing novel conoidean venoms: Biodiverse lumun-lumun marine communities, an untapped biological and toxinological resource. Toxicon 56: 1257-1266. http://dx.doi.org/10.1016/j.toxicon.2009.12.002

Smith B.D. 2003. Prosobranch gastropods of Guam. Micronesica 35/36: 244-270.

Sysoev A.V. 2008. Turridae. In: Poppe G.T. (ed.) Philippine Marine Mollusks, Volume II: 732-815. ConchBooks, Hackenheim, Germany.

Tamura K., Peterson D., Peterson N., Stecher G., Nei M. \& Kumar S. 2011. MEGA5: Molecular Evolutionary Genetics Analysis using Maximum Likelihood, Evolutionary Distance, and Maximum Parsimony Methods. Molecular Biology and Evolution 28: 2731-2739. http://dx.doi.org/10.1093/ $\underline{\text { molbev/msr121 }}$

Tröndlé J. \& Boutet M. 2009. Inventory of marine molluscs of French Polynesia. Atoll Research Bulletin 570: $1-87$.

Tucker J.K. 2004. Catalog of Recent and fossil turrids (Mollusca: Gastropoda). Zootaxa 682: 1-129.

Manuscript received: 19 January 2016

Manuscript accepted: 23 May 2016

Published on: 1 February 2017

Guest editors: Line Le Gall, Frédéric Delsuc, Stéphane Hourdez, Guillaume Lecointre

and Jean-Yves Rasplus

Desk editor: Danny Eibye-Jacobsen

Printed versions of all papers are also deposited in the libraries of the institutes that are members of the EJT consortium: Muséum national d'Histoire naturelle, Paris, France; Botanic Garden Meise, Belgium; Royal Museum for Central Africa, Tervuren, Belgium; Natural History Museum, London, United Kingdom; Royal Belgian Institute of Natural Sciences, Brussels, Belgium; Natural History Museum of Denmark, Copenhagen, Denmark; Naturalis Biodiversity Center, Leiden, the Netherlands. 